Volume 3 Nomor 1, Januari-Juni 2019: hlm. 35-40.

Magister Ilmu Hukum, Fakultas Hukum, Universitas Lampung,

Bandar Lampung, Lampung, Indonesia.

E-ISSN: 2598-3105 P-ISSN: 2723-2581

http://jurnal.fh.unila.ac.id/index.php/cepalo

\title{
PENANGANAN PASCA KONFLIK SOSIAL DI LAMPUNG SELATAN (STUDI PADA WILAYAH POLDA LAMPUNG)
}

\section{POST SOCIAL CONFLICT MANAGEMENT IN SOUTH LAMPUNG (STUDIES IN LAMPUNG REGIONAL POLICE)}

\author{
Saputro Prayitno \\ Institut Teknologi Sumatera \\ saputro.prayitno@gmail.com
}

\begin{abstract}
Abstrak
Bentrokan antara Desa Balinuraga dan Desa Agom, disebabkan oleh pelecehan seksual di mana ada fitnah kepada orang Bali oleh orang Lampung. Permasalahan yang diangkat adalah faktor-faktor penyebab konflik sosial, upaya penanganan dan faktor penghambat dari Kepolisian, Pemerintah Daerah dan Tokoh Masyarakat / Tokoh Adat / Tokoh Agama dalam menangani konflik pascakonflik di Lampung sebagai upaya memberikan legalitas. kepastian dan perlindungan hukum bagi masyarakat luas terutama masyarakat di Lampung Selatan. Penelitian ini bertujuan untuk mengetahui penyebab konflik, penanganan pascakonflik terhadap konflik sosial pada masyarakat Lampung Selatan dan penghambatan penanganan pascakonflik pada konflik sosial di masyarakat Lampung Selatan. Tipe penelitian ini adalah penelitian deskriptif analitis dengan menggunakan pendekatan masalah hukum normatif (penelitian hukum kepustakaan). Penelitian ini menggunakan data sekunder berupa bahan hukum sekunder, yakni buku-buku para ahli ilmu hukum.

Hasil penelitian menunjukkan bahwa terdapat alasan yang dapat memunculkan konflik social di Lampung Selatan, seperti kurangnya pekerjaan; Konflik yang belum terselesaikan; Faktor kesenjangan sosial; Kurangnya komunikasi yang menyebabkan kebingungan dalam kepastian suatu berita; Ada pihak yang menginginkan perpecahan antara kedua desa. Penanganan pasca konflik dilakukan oleh Pemerintah Daerah, Kepolisian Daerah Lampung dan Tokoh Masyarakat / Tokoh Adat / Tokoh Agama bersama melalui upaya rekonsiliasi, rehabilitasi dan rekonstruksi, kemudian penyuluhan dan penyebaran kebutuhan untuk orang-orang yang sadar akan hukum dan masyarakat harmoni, untuk menciptakan komunitas yang tertib, dan damai. Kesimpulan dari penelitian ini adalah Kepolisian, Pemerintah Daerah yang dibantu oleh masyarakat (tokoh agama, tokoh adat dan tokoh masyarakat) wajib melakukan upaya Pemulihan PascaKonflik yang terencana, terpadu, berkelanjutan, dan terukur melalui upaya rekonsiliasi, rehabilitasi, dan rekonstruksi. Undang-Undang Nomor 7 Tahun 2012 tentang Pengelolaan Konflik Sosial juga mengatur peran masyarakat, dan mendanai penanganan konflik, sehingga masyarakat sadar akan hukum dan harmonis di masyarakat, tertib, dan damai.
\end{abstract}

Kata Kunci: Penanganan, Pascakonflik, Konflik Sosial.

\section{Abstract}

The clash between Balinuraga Village and Agom Village was caused by sexual harassment where there was a slander to the Balinese by the Lampung people. The issues raised are the factors that cause social conflict, efforts to handle and inhibiting factors from the Police, Local Government and Community Leaders / Customary Leaders / Religious Leaders in handling post-conflict conflicts in Lampung as an effort to provide legality. legal certainty and protection for the wider community, especially people in South Lampung. This study aims to determine the causes of conflict, post-conflict handling of social conflict in South Lampung society and inhibition of post-conflict handling in social conflict in South Lampung society. This type of research is analytical descriptive research using the approach of normative legal problems (library research).

This study uses secondary data in the form of secondary legal materials, the books of legal experts. The results show that there are reasons that can cause social conflict in South Lampung, such as lack of work; Unresolved conflict; Social inequality factor; Lack of communication that causes confusion in the certainty 
of a news; There are those who want a split between the two villages. Post-conflict handling is carried out by the Regional Government, Lampung Regional Police and Community Leaders / Customary Leaders / Religious Leaders together through reconciliation, rehabilitation and reconstruction efforts, then counseling and spreading the need for people who are aware of the law and harmony society, to create a community that is orderly, and peaceful.

The conclusion of this study is that the Police, Local Government assisted by the community (religious leaders, traditional leaders and community leaders) must make a planned, integrated, sustainable and measurable post-conflict recovery effort through reconciliation, rehabilitation and reconstruction efforts. Law Number 7 of 2012 concerning Management of Social Conflicts also regulates the role of the community, and funds the handling of conflicts, so that the community is aware of the law and harmony in society, orderly, and peaceful.

Keywords: Handling, Post-conflict, Social Conflict.

Cara Mengutip (How to Cite): Saputro Prayitno, "Penanganan Pasca Konflik Sosial di Lampung Selatan (Studi Pada Wilayah Polda Lampung)”, Jurnal Cepalo, 3 (1), (2019): 35-40.

DOI: https://doi.org/10.25041/cepalo.v3no1.1788

\section{A. Pendahuluan}

Indonesia adalah Negara hukum sebagaimana yang diatur dalam Pasal 1 Ayat (2) UUD NRI Tahun 1945, bukan berdasarkan atas kekuasaan belaka. Pernyataan ini menjelaskan bahwa Indonesia adalah negara yang berideologi atas hukum, ideologi untuk menciptakan ketertiban, keamanan, keadilan serta kesejaheraan bagi warga negaranya. Konsekuensi dari itu semua adalah bahwa hukum mengikat setiap perbuatan yang dilakukan oleh warga negara indonesia. ${ }^{1}$ Belakangan ini di Indonesia sering muncul peristiwa yang menunjukkan gerak atau perilaku perbuatan maupun tindakan kekerasan yang bersifat kolektif, misalnya saja peristiwa tawuran anak sekolah, bentrok antar desa, tawuran suporter sepakbola, sampai pada perusakan, penjarahan, pembakaran, penghancuran, penganiayaan, dan sampai dengan perbuatan menghilangkan nyawa orang lain.

Tindakan kekerasan kolektif, ada yang disebut tindakan reaksi sosial. Menurut Abdulsyani, reaksi masyarakat diartikan sebagai tanggapan dari masyarakat terhadap adanya kriminalitas. ${ }^{2}$ Reaksi itu terjadi ketika rasa ketentraman dan kesejahteraan serta kestabilitasan dalam kehidupan bermasyarakat terganggu. Reaksi dapat berupa perbuatan maupun tindakan balasan terhadap berbagai penyimpangan-penyimpangan tersebut. Misalnya pembakaran dan perusakan oleh massa masyarakat suku lampung terhadap rumah masyarakat suku bali. Namun apabila melihat beberapa kasus kekerasan yang telah disebutkan di awal, salah satunya konflik sosial yang terjadi di masyarakat Lampung Selatan, contoh kasus tersebut dapat diketegorikan bukan tanggapan atas suatu tindakan kriminalitas, namun dapat dikatakan sebagai reaksi sosial.

Konflik sosial yang terjadi antara kedua desa, yaitu Desa Balinuraga dengan Desa Agom, di sebabkan karena pelecehan seksual dimana adanya fitnah kepada warga masyarakat suku Bali yang dilakukan oleh oknum masyarakat Lampung. Kronologis kejadian pada hari Sabtu, tanggal 27 Oktober 2012 pukul 17.30 WIB. Telah terjadi kecelakaan lalu lintas di jalan Lintas Way Arong Desa Sidorejo (Patok) Kab. Lampung Selatan antara sepeda roda dua yang dikendarai oleh suku Bali di tabrak oleh sepeda motor yang dikendarai Nurdiana yang berumur sekitar 17 tahun warga Desa Agom Kec. Kalianda Kab. Lampung Selatan berboncengan dengan Eni yang berumur sekitar 16 tahun warga Desa Negri Pandan Kec. Kalianda Kab. Lampung Selatan. Pada peristiwa tersebut warga suku Bali memberikan pertolongan terhadap Nurdiana dan Eni, namun warga suku Lampung lainnya memprovokasi bahwa warga suku Bali telah memegang dada Nurdiana dan Eni. Sehingga pada hari Sabtu 27 Oktober 2012 pukul 22.00 WIB, warga suku Lampung berkumpul di pasar patok melakukan penyerangan ke pemukiman warga suku Bali di Desa Balinuraga Kec. Way Panji. Selanjutnya warga suku Lampung menyerang warga masyarakat Bali di Desa Balinuraga pada hari Minggu tanggal 28 Oktober 2012 pukul 01.00 WIB. Selanjutnya, puncak konflik terjadi pada hari Senin tanggal 29 Oktober 2012 pukul $10.00 \mathrm{WIB}$, saat warga Lampung menyerang secara serentak di Desa

\footnotetext{
${ }^{1}$ Chainur, Arrasjid, Pengantar Ilmu Hukum, Medan: Yani Coprporation, (1988), hlm. 11.

${ }^{2}$ Abdulsyani, Sosiologi Kriminalitas, Bandung: Remadja Karya, (1987), hlm. 92.
} 
Balinuraga. ${ }^{3}$

Dalam penanganan kasus tersebut diatas mengenai konflik sosial yang terjadi di masyarakat Lampung Selatan sudah diselesaikan secara baik yaitu baik secara penal (peradilan) maupun Non Penal (adat). Namun dilihat dari aspek hukum terhadap konflik sosial tersebut tidak terlepas dari fungsi norma yang berlaku ditengah-tengah masyarakat. Sebagaimana yang telah disebutkan bahwa Indonesia adalah negara hukum yang berdasarkan undang-undang dan Pancasila dengan menjunjung tinggi nilai-nilai berkepribadian luhur, bermoral, beretika, berakhlak mulia, dan beriman serta bertakwa Kepada Tuhan Yang Maha Esa, maka perlu adanya penanganan khusus terkait dengan penanganan pasca konflik terhadap konflik sosial di masyarakat Lampung Selatan tersebut. Mengenai hal ini, maka pemerintah wajib melakukan identifikasi guna meredam potensi konflik semakin meluas, sebagaimana tercantum dalam Pasal 9 Undang-Undang Nomor 7 Tahun 2012 tentang Penanganan Konflik Sosial yang menyatakan:

"Pemerintah dan pemerintah daerah berkewajiban meredam potensi konflik dalam masyarakat dengan:

a. melakukan perencanaan dan pelaksanaan pembangunan yang memperhatikan aspirasi masyarakat;

b. menerapkan prinsip tata kelola pemerintahan yang baik;

c. melakukan program perdamaian di daerah potensi Konflik;

d. mengintensifkan dialog antarkelompok masyarakat;

e. menegakkan hukum tanpa diskriminasi;

f. membangun karakter bangsa;

g. melestarikan nilai Pancasila dan kearifan lokal; dan

h. menyelenggarakan musyawarah dengan kelompok masyarakat untuk membangun kemitraan dengan pelaku usaha di daerah setempat.

Identifikasi akan adanya atau telah terjadinya konflik sosial dapat juga di atasi sejak dini sesuai dengan Pasal 10 Undang-Undang Nomor 7 Tahun 2012 tentang Penanganan Konflik Sosial yang menyatakan:

1. Pemerintah dan Pemerintah Daerah membangun sistem peringatan dini untuk mencegah:

a. Konflik di daerah yang diidentifikasi sebagai daerah potensi Konflik; dan/atau;

b. perluasan Konflik di daerah yang sedang terjadi Konflik.

2. Sistem peringatan dini sebagaimana dimaksud pada Ayat (1) dapat berupa penyampaian informasi mengenai potensi Konflik atau terjadinya Konflik di daerah tertentu kepada masyarakat;

3. Pemerintah dan Pemerintah Daerah membangun sistem peringatan dini sebagaimana dimaksud pada Ayat (1) dan Ayat (2) melalui media komunikasi.

Selain pemerintah, masyarakat juga dapat berperan serta dalam melakukan pencegahan terhadap penanganan konflik sosial, sebagaimana tercantum dalam Pasal 52 Undang-Undang Nomor 7 Tahun 2012 tentang Penanganan Konflik Sosial yang menyatakan :

1. Masyarakat dapat berperan serta dalam Penanganan Konflik;

2. Peran serta masyarakat sebagaimana dimaksud pada Ayat (1) dapat berupa:

a. Pembiayaan;

b. Bantuan teknis;

c. Penyediaan kebutuhan dasar minimal bagi korban konflik; dan/atau

d. Bantuan tenaga dan pikiran.

3. Ketentuan lebih lanjut mengenai peran serta masyarakat dalam Penanganan Konflik diatur dengan Peraturan Pemerintah.

Berdasarkan latar belakang tersebut maka diperlukan adanya analisis terkait "Penanganan Pasca Konflik Sosial di Lampung Selatan (Studi Pada Wilayah Polda Lampung)". Penelitian ini bertujuan untuk mengetahui penyebab konflik, penanganan pascakonflik terhadap konflik sosial pada masyarakat Lampung Selatan dan penghambatan penanganan pascakonflik pada konflik sosial di masyarakat Lampung Selatan. Tipe penelitian ini adalah penelitian deskriptif analitis dengan menggunakan pendekatan masalah hukum normatif (penelitian hukum kepustakaan). Penelitian ini menggunakan data sekunder berupa bahan hukum sekunder, yakni buku-buku para ahli ilmu hukum.

\footnotetext{
https://www.kompasiana.com/anharwahyu/5518df8a813311eb719de0b3/perang-suku-di-lampung-sebuah-dendam-lama?page=all dikutip pada tanggal 15 Juli Pukul 19.40 Tahun 2019.
} 


\section{B. Pembahasan}

Konflik sosial yang terjadi pada rentang waktu pada tanggal 27 sampai 29 Oktober Tahun 2012 lalu melibatkan masyarakat Desa Agom Kecamatan Kalianda dan Desa Balinuraga Kec. Way Panji. Jarak kedua desa ini kurang lebih lima kilometer dan dipisahkan dua desa yaitu Desa Taman Agung dan Desa Sidorejo.

Secara geografis kedua desa yang terlibat dalam konflik sosial pada tahun 2012 tersebut jarak antara kedua desa sekitar 8-9 Km. Sedangkan jumlah penduduk Desa Agom dengan luas wilayah $630 \mathrm{ha} / \mathrm{m}^{2}$ dihuni oleh sekitar 2.840 jiwa atau berjumlah sekitar 791 KK. Penduduk Desa Agom didominasi oleh suku pribumi Lampung dan suku jawa, selain itu terdapat suku pendatang lainnya seperti sunda, betawi, dan batak. Mata pencaharian sebagian besar penduduk Desa Agom sebagai petani dengan tingkat pendidikan rendah.

Secara geografis, Desa Agom berbatasan dengan beberapa desa lainnya, diantaranya: ${ }^{4}$

a. Sebelah Barat berbatasan dengan: Desa Taman Agung Kec. Kalianda.

b. Sebelah Timur berbatasan dengan: Desa Sukatani Kec. Kalianda.

c. Sebelah Selatan berbatasan dengan: Desa Merak Belantung Kec. Kalianda.

d. Sebelah Utara berbatasan dengan: Kecamatan waypanji. (RPJM Desa 2016-2021, II-1).

Menurut RPJM Desa Agom, Jarak dari desa ke pusat pemerintahan adalah sebagai berikut: ${ }^{5}$

a. Jarak desa ke ibu kota kecamatan: $16 \mathrm{Km}$.

b. Waktu tempuh ke kecamatan: 15 Menit.

c. Jarak tempuh ke ibu kota kabupaten: $15 \mathrm{Km}$.

d. Waktu tempuh ke kabupaten: 15 Menit.

Berbeda dengan Desa Agom yang didirikan oleh masyarakat pribumi. Desa Balinuraga adalah desa yang didirikan dan dikembangkan oleh masyarakat transmigran Bali yang sejak berpuluh-puluh tahun bermukim di tanah Lampung. Sebelum menjadi bagian dari Kabupaten Lampung Selatan. Desa Balinuraga termasuk dalam teritorial daerah Kabupaten Lampung Timur. Setelah masuk dalam wilayah Kabupaten Lampung Selatan Desa Balinuraga termasuk wilayah Kecamatan Sidomulyo yang juga menjadi bagian dari Kecamatan Way Panji. Jumlah penduduk Desa Balinuraga yang memiliki luas wiayah $920 \mathrm{Ha} / \mathrm{m} 2$ dan masyarakat yang mendudukinya berjumlah sekitar 2200 jiwa atau $500 \mathrm{KK}$.

Penduduk Balinuraga merupkan suku Bali yang beragama Hindu dan mayoritas penduduknya bermata pencaharian sebagai petani karet dan sawit. Jenjang pendidikan di Desa Balinuraga masih terbilang rendah. Pola pemukiman di Balinuraga terpola seperti kompleks perumahan, jarak antara rumah saling berdekatan. Desa Balinuraga bukan satu-satunya pemukiman dengan penduduk murni suku Bali, diwilayah yang masih berdekatan dengan Desa Balinuraga terdapat pula desa dengan penduduk murni suku Bali, yaitu Desa Bali Napal dan Desa Sidoreno.

Desa Balinuraga berbatasan dengan beberapa desa lainnya, diantaranya :

a. Sebelah Utara: Desa Trimomukti Kec. Candipuro

b. Sebelah Selatan: Desa Sidoreno Kec. Way Panji

c. Sebelah Barat: Desa Way Gelam Kec. Candipuro

d. Sebelah Timur: Desa Tanjung Jaya Kec. Palas. (Rencana Pembangunan Jangka Menengah Desa Balinuraga, BAB II Profil Desa)

Sedangkan letak Desa Balinuraga berdasarkan RPJM, Jarak dari desa ke pusat pemerintahan adalah sebagai berikut :

a. Jarak dari ibu kota kecamatan: $5 \mathrm{KM}$

b. Lama jarak tempuh ke ibu kota kecamatan: 15 menit

c. Jarak ke ibu kota kabupaten: $18 \mathrm{KM}$

d. Lama jarak tempuh ke ibu kota kabupaten: 35 menit. $^{6}$

Konflik yang terjadi di Desa Sidorejo Kecamatan Sidomulyo disebabkan oleh kekesalan masyarakat Lampung akan sikap dan perilaku tidak baik yang ditimbulkan oleh pemuda Bali sejak lama hingga terjadi kecelakaan yang dialami oleh 2 pemudi dari Desa Agom mengakibatkan luka-luka dan kesalahpahaman yang tidak bisa dihindari dari kedua masyarakat tersebut hingga mengakibatkan konflik yang besar hingga perang antar desa yang terjadi di Kabupaten Lampung Selatan. Proses mediasi yang melibatkan tokoh-tokoh masyarakat dari kedua belah pihak di tentukan sesuai dengan Keputusan Gubernur Lampung nomor G/685/B.II/HK/2012 yang mana isi dari keputusan tersebut terdapat susunan panitia pelaksanaan deklarasi

\footnotetext{
${ }^{4}$ Adi Saputra, Relasi Sosial Pasca-Konflik Di Lampung Selatan (Studi Kasus Konflik Etnis Kabupaten Lampung Selatan Tahun 2012), Jakarta: Fakultas Ilmu Sosial Dan Ilmu Politikuniversitas Islam Negeri Syarif Hidayatullah, (2017), hlm.38-39.

${ }^{5}$ Adi Saputra, Op.Cit., hlm. 40.

${ }^{6}$ Adi Saputra, Op.Cit., hlm. 47.
} 
dan sosialisasi perdamaian masyarakat Lampung Selatan yang ditetapkan pada tanggal 11 November Tahun 2012.

Penanganan pasca konflik dilakukan oleh Pemerintah Daerah, Kepolisian Polda Lampung serta Tokoh Masyarakat/Tokoh Adat/Tokoh Agama bersama-sama melalui upaya rekonsiliasi, rehabilitasi dan rekonstruksi, kemudian selanjutnya dilakukannya penyuluhan maupun sosialisasi tentang perlunya masyarakat yang sadar hukum dan kerukunan bermasyarakat, guna menciptakan masyarakat yang tertib, tentram dan damai. Selanjutnya, dengan mendasarkan kepada Undang-Undang Nomor 7 Tahun 2012, Presiden RI mengeluarkan Inpres Nomor 2 Tahun 2013 tentang penanganan gangguan keamanan dalam negeri. Diterbitkannya Inpres tersebut dimaksudkan untuk meningkatkan efektifitas penanganan gangguan keamanan secara terpadu, terpadu antar dan instansi terkait.

Pemerintah Daerah, beserta Kelembagaan (Kepolisian, LSM, Mahasiswa) serta Tokoh Masyarakat/Tokoh Adat/Tokoh Agama memiliki peran melakukan upaya Pemulihan Pasca Konflik secara terencana, terpadu, berkelanjutan, dan terukur melalui upaya rekonsiliasi, rehabilitasi, dan rekonstruksi. Undang-Undang Nomor 7 Tahun 2012 tentang Penanganan Konflik Sosial juga mengatur mengenai peran serta masyarakat, dan pendanaan penanganan konflik. Dalam meredam dan menyelesaikan persoalan konflik, Pemerintah dan Pemerintah Daerah dapat menggunakan cara yang sering digunakan dalam penyelesaian konflik yaitu dengan melakukan negosiasi, mediasi dan fasilitasi.

Penanganan pasca konflik terhadap konflik sosial di Lampung Selatan masalah Konflik yang terjadi antar Desa Agom dan Desa Balinuraga, penulis menemukan adanya hambatan dalam menangani masalah penanganan pasca konflik tersebut. yaitu :

1. Faktor Hukumnya sendiri atau peraturannya sendiri;

Salah satu faktor penghambat dalam penanganan pasca konflik di masyarakat Desa Agom dan Desa Balinuraga belum adanya aturan-aturan pemerintah daerah yang jelas dan mengikat. Penegakan hukum pun tidak dapat dilaksanakan demi menjaga stabilitas keamanan di daerah rawan konflik, sehingga resiko adanya konflik antar suku, ras dan agama masih berpeluang kembali terjadi.

2. Faktor penegak hukum;

Penataan kembali kelambagaan penegak hukum Kepolisian, pemerintah daerah maupun Lembaga Swadaya Masyarakat serta para Tokoh Adat/Tokoh Agama/Tokoh Masyarakat agar stabilitas pemulihan keamanan, dan perdamaian di masyarakat dapat terwujud dengan baik, sebagaimana yang diatur dalam Pasal 40 Undang-Undang Nomor 7 Tahun 2012 tentang Penanganan Konflik Sosial.

3. Faktor sarana dan fasilitas;

Penanganan Pasca konflik sosial di daerah Lampung Selatan masih terkendala. Salah satu yang menjadi kendala adalah karena ketiadaan anggaran khusus untuk menangani pasca konflik sosial. Upaya pemulihan kondisi di masyarakat masih minim, dikarenakan tidak adanya anggaran yang yang cukup untuk mendukung kegiatan ekonomi dan fasilitas-fasilitas umum di Desa Agom maupun Desa Balinuraga, mengakibatkan masyarakat merasa kehadiran pemerintah dalam pembangunan yang tidak merata di kedua desa yang berkonflik maupun daerah lainnya di Pemerintah Daerah Kabupaten Lampung Selatan.

4. Faktor sosial dan budaya

Masyarakat Lampung khususnya Desa Agom dan Desa Balinuraga memiliki beraneka ragam budaya sehingga dalam menyikapi permasalahan konflik tersebut masing-masing melihat berdasarkan sudut pandang yang berbeda. Adanya ketidakjelasan sikap dan informasi sebab musabab timbulnya konflik. Sedangkan faktor sosial dapat dilihat dari bagaimana penanganan pasca konflik antara masyarakat Desa Agom dan Desa Balinuraga. Hal ini juga menjadi faktor penghambat dalam penanganan paska konflik di masyarakat Lampung Selatan yaitu Desa Agom dan Desa Balinuraga.

Perbedaan tradisi, adat dan kultur budaya serta kehidupan sosial kedua desa menjadi pekerjaan rumah

bagi pemerintah daerah untuk memajukan kehidupan sosial dalam kehidupan bermasyarakat.

1. Perbedaaan Suku Ras dan Agama pun ikut serta dalam faktor penghambat penanganan dalam penanggulangan konflik sosial antar Desa Agom dan Desa Balinuraga, karena suku lampung yang dengan kereligiusannya dalam beribadah dan sebagai suku asli lampung.

2. Adanya ketertutupan oleh masyarakat Desa Agom sebagai penduduk asli maupun Desa Balinuraga sebagai penduduk pendatang dalam komunikasi hidup bermasyarakat.

\section{Kesimpulan}


Penanganan pasca konflik terhadap konflik sosial yang terjadi di masyarakat Lampung Selatan melibatkan seluruh aspek baik dari elemen pemerintahan maupun masyarakat seperti, Tokoh masyarakat/Tokoh Adat/Tokoh Agama dan yang lainnyadari kedua belah pihak desa yang berkonflik sudah cukup tepat, yang kemudian peran Pemerintah Daerah, kepolisian Polda Lampung, serta Tokoh masyarakat/Tokoh Adat/Tokoh Agama pun juga sangat membantu dalam pencegahan adanya timbul konflikkonflik lainnya dimasa yang akan datang, baik di daerah Lampung Selatan khususnya, demi terciptanya masyarakat yang aman, tentram dan damai.

\section{Ucapan Terima Kasih}

Saya ucapkan terima kasih kepada seluruh pihak yang telah memberikan dukungan dan membantu dalam penyusunan serta penyelesaian tulisan jurnal ini, terutama kepada Institut Teknologi Sumatera yang telah membantu memberikan beasiswa bantuan bagi tenaga kependidikan untuk berkesempatan melanjutkan studi pendidikan. Kepada kedua orang tua (papah (almarhum) dan mama), istri, dan kedua orang tua (mertua), serta keluarga besar saya yang tiada hentinya memberikan support moral untuk penyelesaian penelitian ini. Kepada Prof. Dr. Sunarto, S.H., M.H., selaku Pembimbing Utama dan Dr. Eddy Rifai, S.H., M.H., selaku Pembimbing Pendamping saya ucapkan terima kasih atas ilmu dan bimbingannya selama penyusunan tulisan penelitian ini. Semoga tulisan penelitian ini dapat menjadi refrensi bacaan bagi masyarakat umumnya dan mahasiswa khususnya.

\section{A. Buku}

\section{DAFTAR PUSTAKA}

Abdulsyani. (1987). Sosiologi Kriminalitas. Bandung: Remadja Karya.

Chainur, Arrasjid, (1988). Pengantar Ilmu Hukum. Medan: Yani Coprporation.

Ilham, Bisri. (1998). Sistem Hukum Indonesia. Jakarta: Grafindo Persada.

Ishaq. (2012). Dasar-Dasar Ilmu Hukum. Jakarta: Sinar Grafika.

Soekanto, Soerjono. (1989). Suatu Tinjauan Sosiologi Hukum Terhadap Masalah-Masalah Sosial. Bandung: Citra Aditya Bakti.

Saputra, Adi. (2012). Relasi Sosial Pasca-Konflik Di Lampung Selatan (Studi Kasus Konflik Etnis Kabupaten Lampung Selatan Tahun. Jakarta: Fakultas Ilmu Sosial Dan Ilmu Politik Universitas Islam Negeri Syarif Hidayatullah.

\section{B. Internet}

Kompasiana. (2012). Perang Suku di Lampung Sebuah Dendam Lama. Available online from: https://www.kompasiana.com/anharwahyu/5518df8a813311eb719de0b3/perang-suku-di-lampungsebuah-dendam-lama?page=all. Accessed July 15, 2019. 